\title{
土壤中の残留農薬の調査における試料採取誤差*
}

\author{
後 藤 真 康 \\ 財団法人残留農薬研究所 \\ 東京都小平市鈴木町 2-772 \\ (昭和 52 年 1 月 7 日受理)
}

\section{Variation of Concentrations of Pesticide Residues in Field Soil*}

\author{
Shinko Goto \\ Institute of Environmental Toxicology, Kodaira, Tokyo 187, Japan
}

\begin{abstract}
The variation of concentrations of pesticide residues in soil samples collected from farms was investigated. Four increments $(500 \mathrm{~g})$ of soil were collected from a strawberry garden 0 and 1 day after spraying DDVP emulsion, and their DDVP concentrations were determined individually. Twenty increments were taken from a spinach garden 0 and 7 days after spraying diazinon emulsion. Four increments were used for determination of diazinon contents individually. The remaining were mixed by four increments and resulting 4 samples were analysed. Fifteen increments of soil were collected from a paddy field of rice 0 to 7 days after application of diazinon granule. The increments were divided to 3 increment samples and 3 mixed samples by treating as mentioned above, and diazinon concentration in each sample was determined. The results are summarized in Table 1 . The average of the coefficients of variation (CV) of the increment analysis and that of the analysis of mixed samples were $52 \%$ and $26 \%$, respectively. In the soil-persistency test, the half life (HL) of a chemical in soil is calculated from the slope of the regression line $(A)$ of logarithms of the chemical concentrations $(Y)$ and intervals $(X)$ after application of the chemical. If HL of a chemical and CV are 12 months and $25 \%$ respectively and samples are collected $0,4,8$ and 12 months after the application, the standard deviation (s) of $Y$ and the error of $A$ are calculated as 0.11 and 0.012 , respectively, and the confidence limit of $\mathrm{HL}$ is estimated as 3.9 months- $\infty$. If $X$ are $0,3,6,9,12$ and 15 , the error of $A$ and the confidence limit of $\mathrm{HL}$ are estimated as 0.0087 and 6.1 months-25 years, respectively. To reduce the confidence limit of the estimated HL, not only CV should be decreased but the number of $X$ should be increased.
\end{abstract}

緒

\section{言}

農薬の土㙵での残留性を围場において調査する場合， 同一固場内における土壤中の濃度が散布むら等により不 均一であるため, 試料採取に伴う䛊差により結果が混乱 し解析が困難になることが多い. しかし，その変動の程 度を実際に測定した例は少ない。そこで，いちご畑に DDVP 戍を，伍うれんそう畑および水田にダイアジノ ン鼡を散布したあとの戋場における土㙵中農薬の变動を 測定し，若干の考察を試みた。

* 曟薬の土袞残留試験方法に関する研究（第 3 報）

Study on Soil-Persistency Test of Pesticide (Part 3)
実験

\section{1. 試料の調製}

1）いちご畑の DDVP

いちご烟（国分寺市北町, 火山灰埴壤土, $23 \mathrm{~m}^{2}$ ) の収 穫適期に DDVP $75 \%$ 乳郕の 1,000 倍液 $150 l / 10$ a 小型噴霧器で散布した. 散布直後および 1 日後に圈場内 の任意の地点 4 カ所から直径 $5 \mathrm{~cm}$ のサンプリングボー ラを用い深さ $10 \mathrm{~cm}$ までの土塨を 1 力所約 $500 \mathrm{~g}$ 採取 し，別々によく混合して分析に供した.

2）ほうれんそう畑のダイアジノン

ほうれえそう畑 (国分寺市北町, 火山灰埴士, $42.5 \mathrm{~m}^{2}$ ) 
の収穫適期にダイアジノン $45 \%$ 乳剂の 600 倍液を 150 $l / 10 \mathrm{a}$ ，噴霧器で散布した。散布直後および 1 週後に固 場の任意の地点 20 カ所から 1）と同じ方法で土堙を採 取した。このうち 4 個はそれぞれよく混合して分析に供 し (個別試料)，のこり 16 個は任意に 4 個ずつあわせて よく混合し，4 個の混合試料として分析に供した.

3）水田のダイアジノン

水稲植付 1.5 力月後の水田（秋川市下代継，18 a）に ダイアジノン $5 \%$ 粒剤 $4 \mathrm{~kg} / 10 \mathrm{a}$ を散布した。散布当日 および $1,3,7$ 日後に圃場内の任意の地点 15 力所から， 直径 $5 \mathrm{~cm}$ のサンプリングボーラを用いて深さ $10 \mathrm{~cm}$ ま での土塨およびその上部の水を約 $500 \mathrm{~g}$ 採取した。これ を2）之同様に 3 個の個別試料と 3 個の混合試料にわけ て分析に供した。

\section{2. 分析方法}

DDVP はエーテル十フセトン $(7: 3, \mathrm{v})$ 混液で，ダ イアジノンはアセトンで土塨から抽出した。有機溶媒を 減圧留去したのち残液を水でうすめて DDVP は石油エ ーテル，ダイアジノンは $n$-ヘキサンで抽出した。 以下 常法により FTD ガスクロマトグラフで定量した．分析 は各試料 2 回ずつ行ない，その変動係数は約 $10 \%$ であ った. 検出限界は DDVP 0.005 ppm，ダイアジノン 0.008 $\mathrm{ppm}$ ，回収率の平均は DDVP $0.15 \mathrm{ppm}$ 添加で $91 \%$, ダイアジノン $0.2 \mathrm{ppm}$ 添加で $99 \%$ (畑)，打よび $78 \%$ （水田）であった。

\section{結 果と考察}

分析結果を Table 1 亿示す. 個别試料の変動係数 (CV) は 38 59\%, 平均 $52 \%$, その標準偏差 $(s)$ は $9 \%$ であり, 個別試料を 4 個ずつあわせた混合試料の CV は 10〜 $42 \%$ ，平均 $26 \% ， s 14 \%$ である。一般に CV は分析誤 差よりもかなり大きい，薬棛，圃場，施用後の日数によ る差は試料が少ないのではっきりしない，混合試料の分 析值は個別試料 4 個の分析值の平均と考兄られるからそ の誤差は個別試料の誤差の $1 / \sqrt{n}$ すなわち $1 / 2$ となり, 今回の調査結果でもそうなっている。

土潩分析における誤差についての松尾の解説门によれ ば，土塨の特性值は多くの場合対数正規分布をしてお り，たとえば水田作土の $0.2 \mathrm{~N}$ 塩酸可溶性リン酸の一筆 水田内での試料採取による誤差は CV $22 \%$ 程度である という。また，高知県農林技術研究所の調查では，水田 裏作にアルドリン刘を使用し 3 年後の $\mathrm{A}$ 水田 $(10 \mathrm{a})$ より 1 点 $500 \mathrm{~g}$ の土塨を 30 点ランダム採取した場合のディ ルドリン残留量は平均 $\cdot 0.26 \mathrm{ppm}, s=0.089 \mathrm{ppm}$ で CV は $34 \%$ となる。主た，同様にアルドリン施用 4 年後の B 水田 (7a) から 30 点採取した場合は平均值 $0.11 \mathrm{ppm,}$ $s=0.026 \mathrm{ppm}, \mathrm{CV}=23 \%$ であったといわれる ${ }^{2)}$.これ らの調查例は自然の土㙵特性か，薬剤施用後年数がたち 土䁃がかなり均質化された後のものである。したがって 今回の調查結果がこれらの例に比べて変動が大きいのは

Table 1 Variation of pesticide residues in field soil.

\begin{tabular}{|c|c|c|c|c|c|}
\hline Pesticide \& crop & $\begin{array}{c}\text { Days after } \\
\text { spray }\end{array}$ & $\begin{array}{c}\text { Average } \\
\text { (ppm) }\end{array}$ & $\begin{array}{l}\text { Number of } \\
\text { sample }\end{array}$ & $\begin{array}{c}s \\
(\mathrm{ppm})\end{array}$ & $\begin{array}{l}\mathrm{CV} \\
(\%)\end{array}$ \\
\hline DDVP emulsion & 0 & 0.095 & $4^{\mathrm{a}}$ & 0.051 & 54 \\
\hline Strawberry & 1 & 0.068 & $4^{\mathrm{a}}$ & 0.040 & 59 \\
\hline \multirow{2}{*}{ Diazinon emulsion } & $\{0$ & 0.66 & $4^{\mathrm{a}}$ & 0.32 & 56 \\
\hline & $\{7$ & 0.35 & $4^{\mathrm{a}}$ & 0.20 & 57 \\
\hline \multirow{3}{*}{ Spinach } & $\{0$ & 0.49 & $4^{b}$ & 0.14 & 28 \\
\hline & \}$_{7}$ & 0.31 & $4^{\mathrm{b}}$ & 0.03 & 10 \\
\hline & $\int^{0}$ & 1.43 & $3^{\mathrm{a}}$ & 0.83 & 58 \\
\hline \multirow[t]{3}{*}{ Diazinon granule } & $\{1$ & 0.83 & $3^{\mathrm{a}}$ & 0.32 & 39 \\
\hline & 3 & 0.32 & $3^{\mathrm{a}}$ & 0.12 & 38 \\
\hline & $\left(^{0}\right.$ & 1.14 & $3^{b}$ & 0.12 & 11 \\
\hline \multirow{3}{*}{ Rice } & 1 & 1.19 & $3^{b}$ & 0.49 & 41 \\
\hline & 3 & 0.45 & $3^{\mathrm{b}}$ & 0.19 & 42 \\
\hline & 7 & 0.45 & $3^{\mathrm{b}}$ & 0.12 & 27 \\
\hline
\end{tabular}

$s$ : Standard deviation. CV: Coefficient of variation.

a: Incremenets were analysed individually.

${ }^{\mathrm{b}}$ : Four increments were mixed and analysed. 
当然といえよう。果樹園のように散布むらが大きく，樹 上からの薬液の落下によるむらのある固場では, 土壤残 留量のばらつきはさらに大きいと考えてよからう。

土㙵調査における試料採取誤差をどの程度におさえる かは調查の目的によって異なる。たとえば一つの斗場の 污染実態を詳しく把握しょうとするならば，当然，試料 の採取数を多くし，それを個別に分析するかまたは何個 かの混合試料として分析する必要があろう。前述の高知 県の調査では, 許容誤差を $10 \%$ とすればA水田では 45 点, $\mathrm{B}$ 水田では 18 点の試料数を要すると推定している.

現在主として行なわれているのは土壌中での農薬の半 隇期を推定するための調査である。この場合には分析值 の対数安経過日数に対してプロットし，回兴線が 1 本の 直線となる場合は回帰線の傾斜から半隇期が算出され る.すなわち, 残留量の対数を $y$, 経過期間を $x$ と すれば, 回帰式 $y=b-a x$ より半減期 (HL) は $\mathrm{HL}$ $=\log 2 / a=0.3 / a$ として算出される. 仮に残留量の $\mathrm{CV}$ が調査期間中一定であるとし，その值は（現在は 4 試料 を採取し混合して分析することが多いので） $25 \%$ とす る。この場合, 松尾の解説 ${ }^{1)}$ によれば, $y$ は誤差 $\left(s_{y}\right)$ 0.11 をるつ正規分布をなすと考えられる。、主, 半減 期定 12 力月, 試料採取日は $0,4,8,12$ 力月の 4 回 と仮定すれば, $a=0.3 / 12=0.025, a$ の誤差 $\left(s_{a}\right)$ は $s_{y} / \sqrt{\sum x^{2}-\bar{x} \sum x}=0.11 / \sqrt{80}=0.012$ となる。 この值か ら $a$ の $95 \%$ 信頼限界 $a \pm s_{a} t$ を求めると（自由度は 2), $0.025 \pm 0.012 \times 4.3=0.077 \sim-0.023$ となる. これ を HL に換算すると 3.9 カ月 $\infty$ となる. $(a=0$ な ら HL は $\infty, a$ が負とは残留量が増加するととを意味 し通常はありえない.) 1 回の試料採取数をふやして 8 と すれば CV は $18 \%$ となるから，同様の計算により $s_{y}$ $=0.08, s_{a}=0.009, a$ の信頼限界は 0.064 -0.014 と なり, 推定 HL の範囲は 4.7 カ月から 0 となる。一
方, 1 回の試料数は 4 個とし, 採取時期をふやして 0 , $3 ， 6 ， 9 ， 12 ， 15$ 力月の 6 回とすると, $s_{a}=0.11 / \sqrt{158}$ $=0.0087$ となり， $a$ および $\mathrm{HL}$ の範囲（自由度 $=4 ）$ は 0.049 0.001，6.1 力月 25 年となる. このように, 推 定半減期の幅をせまくするためには, 試料数をふやし, あるいは作物からの距離を一定に保って採取を行なうな どの方法により CV を小さくすることも大切であるが， 試料採取回数をふらやし，その時期を適切に選ぶことも有 効である．これまでの計算では回帰線は 1 本の直線であ ると仮定してきたが，実際はこれが曲線となったり折れ まがった線となることも少なくない. 試料採取回数が少 ないと，回帰線が直線であるかどうかを推定することは ほとんど不可能である．この点も考慮すると，残留農薬 の減少状況を把握するための試験においては, 試料採取 回数を少なくとも 6 回以上にふやすことが大切であると 考光られる。

\section{要約}

土塨中の残留農薬の調查における試料採取誤差を, DDVP を散布したいちご畑, ダイアジノン剂を散布した ほうれんそう畑および水田について測定した。インクリ メントを個別に分析した場合の变動係数の平均は $52 \%$ で，4 個のインクリメントを混合して分析した場合は $26 \%$ であった。残留農薬の減少曲線から半減期を推定 する場合の誤差について考察し, 半減期の推定値の幅を 小さくするには試料採取誤差を小さくするとともに，採 取回数をふやし，時期を適切に選ぶことが大切であるこ とを明らかにした。

\section{引 用 文 献}

1）松尾嘉郎： ぶんせき 1976,820

2）高知県農林技術研究所：昭和 48 年度農薬残留に関 する調査ならびに試験成績書，p. 3, 1974 